\title{
STUDENTS-TRANSLATORS PROFESSIONAL COMPETENCE DEVELOPMENT: THEORETICAL OUTLINE
}

\author{
Tatyana Vysotskaya \\ Ukraine
}

\begin{abstract}
The paper deals with the problems of students-translators professional competence development in the framework of terminological expertise acquisition. Terminological work is stated to be one of the key means of translation competence development. The emphasis is made on theoretical aspect of the matter. The clarification of basic concepts - competence, translation competence, and terminological competence - is provided. Translation competence is viewed as a set of several sub-competences, characterizing translator's social, communicative and properly text-oriented skills. Terminological competence is viewed as the constituent of translation competence. The objectives and the tasks of terminological work for Translation students are stated. Curriculum components resulting in terminological expertise acquisition are analyzed. The system of exercises aimed at terminological competence development is outlined.
\end{abstract}

Keywords: students-translators, competence, translation competence, terminological competence, curriculum, terminological expertise acquisition, system of exercises.

In the context of globalization processes intensification, in response to the aspiration of Ukraine to integrate into the European area, there is a constant increase of international collaboration promoting the extension of Ukrainian contacts all over the world. Facing these processes the society creates the growing demand for coherent translation and interpreting. Meetings, negotiations, conferences, assemblies, festivals, exhibitions, sport events, etc. will never be a success without professional language mediators, i.e. translators and interpreters. European Master's in Translation Group states that translators are essential players in facilitating all forms of exchange and integration and promoting linguistic diversity (EMTG, 2009). Thus, it is not surprising that the success of translation completely depends on the level of translator's / interpreter's professional competence development, its thematic, language, intercultural, info mining, and technological areas in particular.

As National Standards of Education in Ukraine are still on the stage of elaboration, at Translation Department of State Higher Educational Institution "National Mining University" (Dnepropetrovsk, Ukraine) we have developed the framework of students-translators professional competence development by the means of terminological expertise acquisition. 
In the process of the framework development the methods of analysis, synthesis and generalization were applied.

The frame work under consideration provides consecutive learning based on subjects continuity, interrelation and balanced distribution of subjects through the curriculum. Positive results of students' final state attestation confirm the validity of the framework.

The aim of this paper is to present the framework adopted in our university.

With this aim in purpose we have to:

- clarify the basic concepts: competence, translation competence, and terminological competence;

- state the objectives and the tasks of terminological work for Translation students;

- $\quad$ analyse curriculum components resulting in terminological expertise acquisition;

- outline the system of exercises aimed at terminological competence development.

For us, competence is the ability of an individual to do a job properly.Itis a set of defined behaviors that provide a structured guide enabling the identification, evaluation and development of the behaviors in individual employees.

Translation competence is viewed as the concept which characterizes the translator's/ interpreter's professional ability to perform communicative mediation in different spheres of knowledge and activities. Recent decades investigations in this field have resulted in numerous publications on the didactic problem of translation competence in Ukraine and abroad. The concept of translation competence has also been reflected in EU Standards of Higher Education.

The concept of "translation competence", created by Israel linguist and translator G. Touri (Touri, 1980), provoked numerous and extended discussions on its essence. As a result, there was a model of translation competence elaborated.

A long lasting discussion on the content of translation competence resulted in the creation of the model combining several sub-competences. The sesubcompetences characterize social, communicative and properly test-oriented skills of the translator. One cannot help noticing the connection of this competence with the Common European Framework of Reference for Languages (CEFR, 1986). Beeby A., Ensinger D., and Presas M. prove the necessity of including additional components into the concept of translational competence (Beeby et al., 2000). According to them translation competence should include linguistic competence (lexical, grammar and discourse 
knowledge and skills), extra-linguistic competence (general knowledge, the knowledge of Translation Theory, Language Theory, cultural knowledge, and the knowledge of translation specific spheres), the competences of the information transfer (the skills of understanding, decoding, paraphrasing, transforming, and translation planning as a whole), professional competence (the ability to use modern technologies of information acquisition and use,the knowledge of the situation at the professional job market), strategic competence (mastering the skills of attention focusing, memory perfection, self-correction, obtaining proper psychophysiological characteristics, such as psychomotor skill, cognitive abilities, certain psychological traits (Липатова \& Литвинов, 2015).

Taking cue from European Master's in Translation group, by translation competence, we mean the combination of aptitudes, knowledge, behaviour and know-how necessary to carry out a given task under given conditions. This combination is recognized and legitimized by a responsible authority (institution, expert) (EMT, 2009).

We also accept the idea of MontaltRessurrecció V., EzpeletaPiorno P., and GarcíaIzquierdo I. (MontaltRessurrecció et al., 2008), according to which mastering text categories is to be recognized as the central component of translation competence. Special emphasis here should be laid on genre, as the practice of translation teaching is based on this notion. The formation and the development of particular professional skills depend on genre. It is also connected with the obvious correlation of genres, styles and methods of translation. The concepts of genre and stylistic type of translation and genre and stylistic standard of translation, elaborated in the process of Translation Theory development, have a reason behind them. Literary, informative and functional sub-types of translation constitute practical realization of genre and stylistic type of translation concept. Genre and stylistic standard of translation combines the requirements the translation is to meet depending on the functional style of the original. Thus, the translation of fiction is assessed by its aesthetic merits, whereas technical translation is assessed by its terminological correctness and the ability to use this text in practice (Липатова \& Литвинов, 2015). The latter fact stipulates the importance of terminological work in the process of translation competence development as the means of terminological expertise acquisition.

The problems of terminology are one of the burning ones in modern Linguistics and Translation Theory. This fact is stipulated by a number of reasons. The first reason of philologists' attention to terminology is attributed to the fact that terminological units of any language fall into the vocabulary layer of key importance. This layer is a rapidly developing one, being in excessive demand among specialists of all branches. The next reason is connected with certain difficulties terminological units may cause to the translators of scientific 
and technical, popular scientific literature as well as to the translators of science fiction, publicistic writings and even fiction. The translation of technical texts is certainly not limited to terminological units rendering by the means of the target language, but still it is the knowledge of terms origin, building, classification and functioning (inside and outside a certain terminological system) that makes adequate translation possible. All these stipulate the necessity of translators' terminological sub-competence development.

Montero Martínez, Silvia and Pamela Faber outline the following set of abilities as a part of terminological sub-competence. According to them, translators need to develop strategies to carry out the following processes:

- the identification and the acquisition of specialized concepts activated in discourse;

- the evaluation, the consultation, and the elaboration of information resources;

- the recognition of inter-linguistic equivalents based on concepts in the specialized field of knowledge ;

- acquired information and knowledge management and the ability to re-use them in future translations (Montero Martínez \& Faber, 2009).

The formation of students-translators' professional competence is realized by the means of all the subjects of the curriculum, focusing on the combination of translation theory and practical skills. In this regard, the subject "Practice of Scientific and Technical Translation from the First Foreign Language (English)" gains special importance, as it results in the acquisition of knowledge of basic special vocabulary and fundamentals of connected text translation and interpreting. The course is also aimed at teaching students general scientific vocabulary as well as special terminological vocabulary of human activity leading branches.

It should be noted that undergraduate Terminology courses in Translation receive much attention in the framework of Translation students training in Ukraine. Comprehensive training of translators in Higher Educational Institutions also involves Terminology course learning. The course is aimed at teaching theoretical fundamentals of Terminology as the Humanity, as well as structural and semantic peculiarities of terms as the object of translation. Thus, Terminology course for Translation students is another important component of terminological competence development.

The course starts on the third year of study after students have had time to reflect on the language mediation process. This reflection naturally leads to the realization that in order to effectively translate specialized texts, a translator must be aware of how to identify and resolve terminology problems (Montalt Ressurreccióet.al., 2008). 
The main objectives of the course, which is designed to provide the knowledge of English Terminology fundamentals for Translation students, are:

1) theoretical aspects of Terminology presentation;

2) English and Ukrainian terminological systems comparison;

3) terminological units' functional and translational peculiarities outlining.

The main tasks of the course are:

1) to provide students with the knowledge of basic concepts and definitions applied in Terminology;

2) to introduce modern terms main types, formation patterns, structural and semantic peculiarities, stylistic and sociolinguistic functions;

3) to teach main means of terms translation in special and not-special texts.

The curriculum also includes a number of Terminology related courses: English Terminology, Basics and Terminology in the Field of Power Engineering, Basics and Terminology in the Field of Electrotechnical Engineering, Basics and Terminology in the Field of Mining, Translation in the Field of Power Engineering, Translation in the Field of Electrotechnical Engineering, Translation in the Field of Mining.

The content of terminological component of undergraduate students training can be organized under the following stages:

1. Introduction to Terminology (English Terminology, 1 ECTS credit).

2. Theory and practice of Terminology (Basics and Terminology in the Field of Power Engineering, Basics and Terminology in the Field of Electrotechnical Engineering, Basics and Terminology in the Field of Mining, 8 ECTS credits).

3. Terminology applied to Industry-specific Translation (Translation in the Field of Power Engineering, Translation in the Field of Electrotechnical Engineering, Translation in the Field of Mining, 15 ECTS credits).

The first stage aims at providing the overview of Terminology as the Humanity:

- basic concepts;

- various approaches to Terminology;

- the distinction between word, term and nomenclature;

- in-branch and inter-branch homonymy of terms;

- terminological word-building;

- the concepts of functional group, main meaning, lexical and semantic group, semantic structure of the word;

- basic classifications of terms. 
On the second stage the emphasis is laid on industry-specific texts as the main domain of terms functioning. Industry-specific terms are studied in their natural environment.

The third stage represents the application of the obtained terminological expertise to translation. It focuses on practical implementation of the gained knowledge and skills.

The organization of in-class activities, including lectures, discussions and debates, stimulates students' active participation in the learning process. Both in-class and independent activities presuppose the work with the system of exercises.

The system of exercise includes:

- $\quad$ reproductive exercises on the levels of word, word-combination and sentence;

- receptive and productive exercises on the level of terminological equivalents, word-combinations, syntagmas;

- $\quad$ receptive and productive exercises on the level of texts.

Independent studies are based on written translation of special texts containing typical translational difficulties, work with dictionaries, terminology learning, and different branches terms glossaries making.

Thus, according to the curriculum Terminological disciplines make up 24 ECTS credits, 684 hours (about 228 hours of in-class work and 456 hours of independent study) with strong focus on practical training (15 ECTS credits). Such practical orientation of the curriculum provides the acquisition of terminological expertise promoting the development of students' translation competence as well as making them competitive on the market of translation services, as the ability to combine theoretical knowledge and practical skills contributes much to adequate translation and successful professional activity.

In near future we are going to develop a questionnaire to get the information on the value of each subject from the students' point of view to identify areas for improvement. We plan to acquire data on students' evaluation of the subject courses, their own participation in the study process and their proposals concerning the courses: the topics that the courses should have covered in a greater depth as well as their likes/dislikes about the courses.

\section{References}

Common European Framework of Reference for Languages: Learning, Teaching, Assessment (1986). Downloaded from http://www.coe.int/t/dg4/linguistic/source/framework_en.pdf.

EMT expert group (2009). Competences for professional translators, experts in multilingual and multimedia communication. Downloaded from http://ec.europa.eu/dgs/translation/ programmes/emt/key_documents/emt_competences_translators_en.pdf. 
Proceedings of the International Scientific Conference. Volume I, May $27^{\text {th }}-28^{\text {th }}, 2016.258-264$

MontaltRessurrecció, V., EzpeletaPiorno, P., \& GarcíaIzquierdo, I. (2008). The Acquisition of Translation Competence. Downloaded from http://www.translationjournal.net/ journal/46competence.htm.

Montero Martínez, Silvia \& Pamela Faber. (2009). Terminological Competence in Translation. In:Terminology 15, o. 1: 88-104. Downloaded from http://dx.doi.org/ 10.1075/term.15.1.05mon.

PACTE (2000). Acquiring Translation Competence: Hipotheses and Methodical Problems in a Research Project. In: Beeby, A., Ensinger, D., Presas, M. Investigating Translation (99-106). John Benjamins Publishing Company.

Touri, G. (1980). In Search of a Theory of Translation. - Tel Aviv: Porter Institute.

Липатова, В.В., \& Литвинов, А.В. (2015). Современная модель профессиональной компетенции переводчика в контексте системы подготовки в языковых вузах. Downloaded from http://www.nop-dipo.ru/ru/node/416 